\title{
The Role of Environmental Tribunals in Pakistan: Challenges and Prospects
}

\author{
Martin Lau*
}

I. Introduction

In Pakistan, the practice and the theory of environmental law manifest themselves in two distinct areas of law. The most prominent of the two is constitutional law. Starting with the landmark decision of Shehla Zia vs. WAPDA in $1994^{1}$, Pakistan's Supreme Court and the four provincial high courts have generated a substantial body of environmental jurisprudence centred on the interpretation and application of the constitutionally guaranteed right to life under Article 9 of the Constitution, 1973. Public interest litigation is the body of environmental law that has received most of the local and international attention, discussion and publicity. ${ }^{2}$ In contrast, there is far less engagement with the jurisprudence generated under Pakistan's environmental framework laws, such as the Pakistan Environmental Protection Act, 1997 and, since 2010, the four provincial environmental protection laws of Punjab, Sindh, Khyber Pakhtunkhwa and Balochistan.

Two reasons for this imbalance can already be identified in this introduction. First, cases under the environmental protection laws are adjudicated by specialist environmental tribunals. It is the duty of the executive to establish and staff these environmental tribunals. For long periods, governments have neglected this duty and as a result, across all four provinces, environmental tribunals have functioned only sporadically. Second, when they do function, only a small proportion of their judgements is reported in Pakistani law reports. As a result, the body of research on Pakistani environmental law, most of it produced by NGOs such as IUCN, WWF and the Asian Development Bank, has not paid much attention to the role and function of environmental tribunals in the enforcement of environmental protection laws.

This article takes a first step towards rectifying this imbalance, aiming to analyse and discuss Pakistan's environmental law regime in the context of the environmental tribunals that adjudicate and ultimately enforce it. The first part travels across the landscape of environmental framework laws in Pakistan, identifying their origins, their foundational and institutional building blocks and the legal techniques and principles that have informed their evolution and development. A selective analysis of the recently enacted provincial environmental protection acts provides the stepping stone to the final

\footnotetext{
* Professor of South Asian Law, School of Law, SOAS, University of London and Barrister, Essex Court Chambers, London. I gratefully acknowledge the valuable assistance provided by Mr Umair Saleem, Advocate High Court (Pakistan), B.A./LL.B. (LUMS) and current LL.M. student at Katholieke Universiteit Leuven, in the research of this article.

${ }^{1}$ Shehla Zia vs. WAPDA PLD 1994 SC 693.

2 Martin Lau, 'The Right to Public Participation: Public Interest Litigation and Environmental Law in Pakistan' (1995) RECIEL, Vol. 4:1, 49-50, Martin Lau, 'A New Dawn: The Chaudhry Court and the Revival of Environmental Law', in: Moeen Cheema and Ijaz Shafi Ghani (eds), The Politics and Jurisprudence of the 'Chaudhry Court' 2005-2013 (OUP, 2014) 141 -159, Parvez Hassan, 'Shehla Zia v. Wapda: Ten Years Later' PLD 2005 J 48, Azim Azfar and Parvez Hassan, 'Securing Environmental Rights through Public Interest Litigation in South Asia' (2004) 22:3 Virginia Environmental Law Journal 215-247.
} 
part which focuses on a discussion of the jurisprudence produced by Pakistan's environmental tribunals from 2008 to the middle of 2019.

Reviewing the jurisprudence produced by Pakistan's environmental tribunals is of critical importance for the reform and development of its environmental law regime. How suitable is the command-and-control approach underlying all of the federal as well as the provincial environmental framework laws? What factors contribute to the success or failure of prosecutions for environmental offences? What is the role of environmental tribunals in enforcing requirements for environmental impact assessments? In answering these questions, this article will assess the status and functioning of Pakistan's environmental tribunals with reference to Brian Preston's seminal 2014 article Characteristics of Successful Environmental Courts and Tribunals ${ }^{3}$. Do Pakistan's environmental tribunals fulfil the criteria identified by Preston as decisive for their success? If not, what are their weaknesses and how can they be addressed?

In announcing the article's aims, its limits ought to be acknowledged too. This work discusses and analyses the reported judgments of environmental tribunals in the context of Pakistan's environmental protection laws but does not include interviews, surveys or questionnaires nor does it consider appeals to high courts and the Supreme Court. All of the 63 judgements discussed in this article are reported in the Corporate Legal Decisions or CLD, a Pakistani law report. Apart from hard copies, CLD can also be accessed through several legal databases, such as the Pakistanlawsite ${ }^{4}$ and the South Asian Law Portal ${ }^{5}$. As a tool for other researchers, appended to this article is a chronological table of all 63 judgements with the date of the filing of the complaint or appeal, the date of the decision and an indication of the nature of the proceedings added.

II. The Evolution of Pakistan's Environmental Framework Laws

\section{a. The Pakistan Environmental Protection Ordinance, 1983}

The very first express mention of environmental law was incorporated in Pakistan's third constitution, the Constitution of $1973 .{ }^{6}$ In the distribution of legislative powers between the provinces and the Federation, "Environmental Pollution and Ecology" was included in the Concurrent Legislative List. Ten years later, it was the military regime of General Zia-ul-Haq that promulgated the Pakistan Environmental Protection Ordinance, 1983 ["PEPO 1983"] as the country's first comprehensive environmental law. PEPO 1983 remained largely unimplemented, but its legal and institutional approach to the control and prevention of environmental pollution have informed its successors, the Pakistan Environmental Protection Act, 1997, and, from 2010 onwards, the four provincial environmental statutes as well as those of the autonomous regions of Gilgit-Baltistan and Azad Jammu and Kashmir.

\footnotetext{
${ }^{3}$ Brian J. Preston, 'Characteristics of Successful Environmental Courts and Tribunals' (2014) 26 Journal of Environmental Law 365.

${ }^{4}$ https://www.pakistanlawsite.com.

${ }^{5}$ https://www.salp.co.

${ }^{6}$ The inclusion of environmental pollution and ecology as areas of legislative competence in 1973 was one the outcomes of Pakistan's participation in the Stockholm Conference on the Human Environment 1972. See Rafay Alam, Situational Analysis of National Environmental Laws and Policies, Non-Compliance of these Laws, Resource Efficiency Issues and Gaps in Implementation and Enforcement (WWF-Pakistan, 2018), 14.
} 
PEPO 1983 established two institutions, a ministerial-level environmental policy making body called the Pakistan Environmental Protection Council and a federal, executive, implementation authority, called the Pakistan Environmental Protection Agency ["EPA"]. The former consisted of the federal and provincial ministers in charge of the subject "environment" and was tasked with the formulation of over-arching environmental policies and directions, such as the establishment of a comprehensive national environmental policy and the inclusion of environmental considerations in national development plans and policies. EPA was charged with the administration of PEPO 1983, including establishing National Environmental Quality Standards ["NEQS"] and to "co-ordinate and consolidate implementation of measures to control pollution with Provincial Governments and other Government agencies. "7 In addition, EPA was to establish and administer an Environmental Impact Statement system, compulsory for all development projects likely to adversely affect the environment. Section 12 of PEPO 1983 made failure to comply with any rule or regulation issued by EPA a criminal offence, punishable by up to two years imprisonment as well as a fine. Starting with Punjab in 1987, EPAs were established in all four provinces ${ }^{8}$ but it was only in 1993, ten years after the promulgation of PEPO 1983, that National Environmental Quality Standards were established ${ }^{9}$. The National Conservation Strategy 1992 assessed PEPO 1983 as "at best a modest attempt to meet Pakistan's growing environmental problems" because it did not address specific areas such as air or water and viewed the environment from the perspective of pollution control rather than resource conservation. Concluding that the "Ordinance has not had an impact on Pakistan's environment", ${ }^{10}$ the National Conservation Strategy 1992 promised a review of existing environmental laws and "to implement the amended environmental laws strictly." 11 Writing in 1993, Tariq Banuri commented that "the EPO has not yet been properly enforced is becoming a matter of embarrassment for the government." 12

\section{b. The Pakistan Environmental Protection Act, 1997}

Five years later, PEPO 1983 was repealed and replaced with the Pakistan Environmental Protection Act 1997 [“PEPA 1997”]. It continues its predecessor's institutional framework of an Environmental Protection Council as top-level policy maker and an implementing, executive Environmental Protection Agency whilst expanding their respective memberships, duties and powers. Now chaired by the Prime

\footnotetext{
${ }^{7}$ Section s. 6 (1)(j) of PEPA 1983. NEQS were announced for the first time in 1993, see: Mujahida Naureen, 'Development of Environmental Institutions and Laws in Pakistan' [2009] 30:1 Pakistan Journal of History and Culture 93, 97

${ }^{8}$ EPAs were established in Punjab in 1987, in Sindh in 1989, in NWFP (now KPK) in 1992 and in Baluchistan in 1995. In the autonomous regions of Gilgit Baltistan and Azad Jammu and Kashmir EPAs were established respectively 2007 and 2005, see Mujahida Naureen, op. cit., 101

${ }^{9}$ Jawad Hassan, Manual of Environmental Laws in Pakistan (Lahore 2018), 944.

${ }^{10}$ Government of Pakistan, The Pakistan National Conservation Strategy: A Plan of Action for the 1990s (Islamabad, 1992)

${ }^{11}$ Ibid., 21

12 Tariq Banuri, 'Implementation of the Environmental Protection Ordinance' (1993) SDIP Policy Paper Series: 4, 1 < https://www.sdpi.org/publications/files/P4-Implementation\%20of\%20the\%20Environmental.pdf> (accessed at 5 July 2019)
} 
Minister himself, the membership of the Pakistan Environmental Protection Council includes 35 so-called "non-official" members drawn from representatives of industry, agriculture, trade unions, non-governmental organisations concerned with the environment and development as well as scientists, technical experts, educators and legal and medical professionals. Its duties and powers now refer expressly to the protection and conservation of species, habitats, and biodiversity and it is "to coordinate integration of the principles and concerns of sustainable development into national development plans and policies." 13

The Environmental Protection Agency is split into a federal and four provincial agencies. Added duties of the federal EPA include the enforcement of the National Environmental Quality Standards, the establishment of quality standards for ambient air, water and land, the promotion of research into "the prevention of pollution, protection of the environment and sustainable development", to recommend "environmental courses, topics literature and books for incorporation in the curricula and syllabi of educational institutions", to prepare safeguards for the prevention of disasters and to "take or cause to be taken all necessary measures for the protection, conservation, rehabilitation and improvement of the environment, prevention and control of pollution and promotion of sustainable development." In addition, the federal EPA can make regulations for realising the objectives of PEPA 1997, such as guidelines for Initial Environmental Examinations ["IEE"] and Environmental Impact Assessments ["EIA"] and the monitoring and measurement of discharges and emissions. ${ }^{14}$ The federal EPA can delegate its powers to the provincial agencies. ${ }^{15}$

Most significantly, PEPA 1997 fulfilled the promise of the National Conservation Strategy 1992 to ensure the enforcement of environmental law. For this objective, PEPA 1997 has adopted two complimentary legal approaches. The first is a commandand-control approach, making environmental pollution a crime to be prosecuted by the EPA and tried in newly established Environmental Tribunals or by designated Environmental Magistrates ${ }^{16}$. With regard to the criminal offence, PEPA 1997 prohibits a number of activities, such as the discharge or emission of any "effluent or waste or air pollutant or noise", including those emitted by motor vehicles in excess of the National Environmental Quality Standards ${ }^{17}$, breaching Environmental Impact Assessment or Initial Environmental Examination requirements ${ }^{18}$ and importing ${ }^{19}$ or unlawfully handling hazardous waste..$^{20}$

\footnotetext{
${ }^{13}$ Section 4 (f) PEPA 1997.

${ }^{14}$ Section 33 PEPA 1997.

15 Section 25 PEPA 1997.

${ }^{16}$ Environmental Magistrates have been given additional powers under a number of rules issued under PEPA 1997, such as the Punjab Polythene Bag Rules, 2004. For more information see Ayesha Malik, The Handbook on Environmental Law, (Punjab Judicial Academy, n.d.) at $<$ http://www.pja.gov.pk/system/files/The\%20Handbook\%20On\%20Environmental\%20Law\%20\%28v4\%29.pdf> accessed on 2 July 2019.

${ }^{17}$ Section 11 PEPA 1997.

${ }^{18}$ Section 12 PEPA 1997.

${ }^{19}$ Section 13 PEPA 1997

${ }^{20}$ Section 14 PEPA 1997.
} 
In addition to a prescriptive command-and-control approach, PEPA 1997 also incorporates mandatory environmental impact assessments for particular types of projects. Section 12 (1) of PEPA 1997 provides that

(1) No proponent of a project shall commence construction or operation unless he has filed with the Federal Agency an initial environmental examination or, where the project is likely to cause an adverse environmental effect, an environmental impact assessment, and has obtained from the Federal Agency approval in respect thereof.

The Environmental Protection Agency (Review of IEE and EIA) Regulations 2000 prescribe the criteria to determine whether a project requires either an initial environmental examination ["IEE"] or an environmental impact assessment [“EAA"]. ${ }^{21}$

Section 17 PEPA 1997 stipulates the penalties for any breach of these prohibitions. For first offenders, there are fines, with continuing offending being penalised by daily fines, and additional fines for those who had gained monetary benefits by committing the crime. Repeat offenders can be imprisoned for up to two years, have their factories closed, their machinery or vehicles confiscated, be ordered to restore the environment at their own cost and to compensate for any damage caused to either persons or property. ${ }^{22} \mathrm{EPA}$ can also offer an accused a plea deal under which the criminal prosecution could be dropped on payment of an administrative penalty. ${ }^{23}$ Section 18 PEPA 1997 makes directors, partners, managers or other officers criminally liable for offences committed by a "body corporate" or, in the case of a company, its Chief Executive. Likewise, section 19 makes heads or officers of any government agency, local authority or local council criminally liable under PEPA 1997.

The EPA is designated as the prosecutor for offences under PEPA 1997. After having afforded them an opportunity to be heard, EPA can issue Environmental Protection Orders ["EPO"] to persons found to be in breach of PEPA 1997. EPOs could include a wide range of directions, such as the immediate stoppage of the polluting activity, the installation or alteration of equipment or the restoration of the environment to the condition prior to the discharge. ${ }^{24}$

Depending on the nature of the breach, non-compliance with an EPO allows the EPA to submit a complaint to either the Environmental Tribunal or the Environmental Magistrate, resulting in a criminal trial. The Environmental Magistrate has exclusive jurisdiction to try offences in relation to the handling of hazardous waste and motor vehicles. All other environmental offences, including the import of hazardous waste, are under the exclusive jurisdiction of the Environmental Tribunal.

\footnotetext{
${ }^{21}$ For a recent assessment of IEE/EAA processes in Pakistan, see Imran Khan, The Current State of Environmental Impact Assessment [EIAs] in Pakistan and the Way Forward, (Heinrich Böll Stiftung, Islamabad, 2017) at < https://pk.boell.org/2017/12/26/current-state-environmental-impact-assessments-eiaspakistan-and-way-forward> (accessed 4 July 2019).

${ }^{22}$ Section 17 PEPA $1997 .^{22}$

${ }^{23}$ Section 17 (7) PEPA 1997. Detailed rules on the compounding of environmental offences were introduced by the Composition of Offences and Payment of Administrative Penalty Rules, 1999.

${ }^{24}$ Section 16 PEPA 1997.
} 
In addition to EPA, an aggrieved person can also make a complaint. In the case of the Environmental Tribunal, any aggrieved person can make a complaint as long as they have given notice of not less than thirty days to the EPA of the alleged contravention and their intention to make a complaint. ${ }^{25}$ For Environmental Magistrates, an aggrieved person can make a complaint without any notice requirement. ${ }^{26}$

The Environmental Tribunal is composed of three members. The Chairperson has to be current or retired judge "who is, or has been, qualified for appointment as a Judge of the High Court". The Chairperson is appointed by the Federal Government after consultation with the Chief Justice of the High Court. At least one of the other two had to be a technical member with suitable professional qualifications and experience in the environmental field ${ }^{27}$. For every sitting of the Environmental Court, the presence of the Chairperson and at least one member is required.

In the exercise of its criminal jurisdiction, the Environmental Tribunal is accorded the power of a Court of Session, in the hierarchy of Pakistani courts the most senior criminal trial court. The High Court hears appeals against decisions of the Environmental Tribunal. Appeals from decisions of the Environmental Magistrate are heard by the Court of Session. The Environmental Tribunal Rules, 1999 stipulate that every effort should be made to dispose of cases within 60 days.

c. The National Environmental Quality Standards (Self-Monitoring and Reporting by Industry) Rules, 2001

An alternative to command and control approach of PEPA 1997 was launched in 2001. The National Environmental Quality Standards (Self-Monitoring and Reporting by Industry) Rules, 2001 and the Pollution Charge for Industry (Calculation and Collection) Rules, 2001 attempted to impose pollution charges on industrial units in order to generate economic incentives for pollution abatement. Whilst it has remained largely unimplemented, the initiative deserves to be discussed for the simple reason that it is Pakistan's only environmental policy that has not relied on criminal law. The scheme linked self-reporting of emissions by industries with the payment of pollution charges. The National Environmental Quality Standards (Self-Monitoring and Reporting by Industry) Rules, $2001^{28}$ required industries to submit Environmental Monitoring Reports. The extent and number of these reports depended on the type of industry. A computer programme named the Self-Monitoring and Reporting Tool (SMART) was supposed to capture the emission data of each participating industrial unit and transmit them to the EPA. With respect to industrial units not using SMART, an inspection team consisting of representatives of the EPA, the industrial unit, of environmental $\mathrm{NGOs}^{29}$ and of certified environmental laboratories would determine the

\footnotetext{
${ }^{25}$ Section 21(3)(b) PEPA 1997.

${ }^{26}$ Section 24 (3)(b) PEPA 1997.

${ }^{27}$ Section 20 PEPA 1997.

${ }^{28}$ Schedule VI 'Form A' of The National Environmental Quality Standards (Self-Monitoring and Reporting by Industry) Rules, 2011.

${ }^{29}$ Schedule II of The National Environmental Quality Standards (Self-Monitoring and Reporting by Industry) Rules, 2011 lists IUCN-Pakistan, WWF-Pakistan, the Sustainable Development Policy Institute in Islamabad as well SUNGI and PAIDAR, two Pakistani NGOs.
} 
factory's pollution level. Once the pollution level had been calculated, industrial units were meant to pay a pollution charge to the government, calculated on the basis of guidelines contained in the Pollution Charge for Industry (Calculation and Collection) Rules, 2001.

Guidelines of the Pollution Charge for Industry (Calculation and Collection) Rules, 2001 explain the scheme's underlying policy considerations: whilst there was a need to make industries more environmentally friendly, they needed time to prepare for compliance with the National Environmental Quality Standards. The level of the pollution charge payable by an individual industrial unit was to be established through a process of negotiations. The charge was meant to be sufficiently high for the industrial unit to feel the impact but not be so excessive as to jeopardize its financial health.

Imran Khalid and Ahmed Awais Khaver conclude that a lack of trust between industries and government resulted in low participation and ultimately failure of the scheme. ${ }^{30}$ The scheme's weak enforcement provisions must be another reason for its failure. The Pollution Charge for Industry (Calculation and Collection) Rules, 2001 simply state that "The Chambers of Commerce and Industry at the Federal and Provincial levels shall use their good offices to ensure that all industrial units in their respective jurisdictions pay the pollution charge in accordance with these rules. "31 Apart from moral pressure, the only other incentive for an industrial unit to pay the pollution charge is indirect. Section 11 (3) of PEPA 1997 provides that "Any person who pays the pollution charge levied under sub-section (2) shall not be charged with an offence with respect to that contravention or failure." The incentive is a weak one, given that the enforcement of criminal sanctions under PEPA 1997 has not been a serious threat to any polluter. Writing in 2013, Irum Ahsan and Saima Amin Khawaja state that the SMART program "is practically noneffective at present." 32

\section{Provincial Environmental Laws}

The Constitution (Eighteenth Amendment) Act, 2010 [" $18^{\text {th }}$ Amendment"] has triggered the most recent and most significant change to the framework of environmental law in Pakistan. Passed in the aftermath of the military regime of General Musharraf, who had resigned in 2008, the 18th Amendment realigned the relationship between the four provinces and the central government, increasing their autonomy and power vis-a vis the centre. One important and far-reaching measure to increase provincial autonomy was the deletion of the Concurrent Legislative List from Part II of the Fourth Schedule of the Constitution 1973. As a result, a wide range of subjects is now within the exclusive legislative competence of the provincial legislatures, including that of "Environmental Pollution and Ecology".

Assessing the potential impact of the $18^{\text {th }}$ Amendment to Pakistan's environmental law regime, the IUCN has stressed that an effective environmental protection depends in

\footnotetext{
${ }^{30}$ Imran S. Khalid and Ahmed Awais Khave, Political Economy of Water Pollution in Pakistan: An Overview (2019) SDIP Working Paper Series: 170, 5.

${ }^{31}$ Section 9 of the Pollution Charge for Industry (Calculation and Collection) Rules, 2001.

${ }^{32}$ Irum Ahsan and Saima Amin Khawaja, Development of Environmental Laws and Jurisprudence in Pakistan (Asian Development Bank, 2013), p. 11.
} 
large part on a uniform protection regime across the country ${ }^{33}$. Separate, provincial legal regimes for environmental protection would create procedural difficulties and could lead to inter-provincial conflict. In addition, the IUCN pointed out that the question of the implementation of Pakistan's international obligations under multilateral environmental treaties had to be addressed not at the provincial but at the level of the federal government, because implementing of treaties and agreements remained a federal subject.

Post- $18^{\text {th }}$ Amendment, five separate environmental protection laws operate in Pakistan. The original Pakistan Environmental Protection Act, 1997 continues to apply in the Islamabad Capital Territory. What used to be the federal Environmental Protection Agency has continued to function, but its reach is now confined to the capital territory. The federal Ministry of the Environment has been abolished and replaced by the federal Ministry of Climate Change. Punjab, Pakistan's most populous province, has retained the existing PEPA 1997 without any changes by simply re-enacting it as the Punjab Environmental Protection Act, 1997 ["the Punjab Act"] ${ }^{34}$. As will be seen in the next section, the re-enactment of PEPA 1997 with just the word "Pakistan" replaced with "Punjab" had far reaching consequences for its enforcement. The rules and regulations that had been made under PEPA 1997 were not amended and hence remained linked to original PEPA 1997 rather than the new Punjab Act. As a result, they had lost their legal validity and could not any longer be applied by Punjab's Environmental Tribunal.

By 2014, the provinces of Sindh, Khyber Pakhtunkhwa and Balochistan had also enacted their own environmental framework laws: the Sindh Environmental Protection Act, 2014 (the "Sindh Act"), the Khyber Pakhtunkhwa Environmental Protection Act, 2014 (the "KPK Act") and the Balochistan Environmental Protection Act, 2012 (the "Balochistan Act"). The wave of legislating new environmental laws also reached the autonomous region of Gilgit-Baltistan, which legislated the Gilgit-Baltistan Environmental Protection Act, 2015. Azad Jammu and Kashmir, the other autonomous and formally independent region, enacted its first environmental protection act in 1996. Four years later, it was repealed and replaced with the Azad Jammu and Kashmir Environmental Protection Act, 2000.

On the whole, the new environmental statutes of Sindh, KPK and Balochistan follow the admonition of the IUCN that "it is of the utmost importance that they [the provinces] to adopt common standards which can subsequently be strengthened by individual provinces but not weakened", ${ }^{35}$ retaining the over-all institutional structure and the command-and-control approach of the original PEPA 1997, including its provisions regarding the establishment and jurisdiction of the Environmental Tribunal and Environmental Magistrates. ${ }^{36}$ However, all three have added new provisions to the original PEPA 1997, either to provide for more detail or to cater for particular

\footnotetext{
${ }^{33}$ Firuza Pastakia, Environmental Protection and the Eighteenth Amendment (IUCN, 2012), 5.

${ }^{34}$ The Punjab Environmental Protection (Amendment) Act, 2012.

${ }^{35}$ IUCN, op. cit., p. 6.

36 The Sindh Act adds a provision to prevent the Environmental Tribunal from becoming non-functional due to the absence of the Chairperson. Section 21 (4) of the Sindh Act provides that "For every sitting of the Tribunal, the presence of the Chairperson and not less than one member shall be necessary. However, in case of non availability of the Chairperson the senior member shall act as a Chairperson till the availability of the Chairperson."
} 
geographic conditions of a province. As a result, the body of Pakistani environmental law is now split along provincial lines, autonomous regions and the capital territory.

Whilst a full review of the new provincial environmental protection acts is beyond the scope of this article, some of the key differences need to be flagged up ${ }^{37}$.

\section{Definitions}

As far as additions are concerned, all three provincial acts aim to be more precise when it comes to the definition of key terms. The most significant additions were made in the KPK Act, which expands some of PEPA's 1997 definitions and adds several new ones. Section 2(b) of the KPK Act widens the definition of "adverse environmental effect" 38 to include "pollution to physical, biological, social, economic environment or to geological, hydrological resources or various land forms; damage to public comfort, aesthetic conditions, ecological balance and meteorological conditions and damage to aquifers, vegetal canopy, cultural heritage or archeological sites". New terms are introduced, such as a definition of "aggrieved person" to be "a person whose legal right is violated by any act or omission or is directly and adversely affected by an order of any authority"; 39 "Biosafety" as "the mechanisms developed through policy and procedure to ensure human health and environmentally safe application of biotechnology";40 and "Climate Change" as "a change of climate which is attributed directly or indirectly to human activity that alters the composition of the global atmosphere and which is in addition to natural climate variability observed over comparable time periods." 41

Section 2 (f) of the Balochistan Act is the only of the provincial environmental protection laws that includes a reference to "best practical environmental option" as meaning "the best method for preventing or minimizing adverse effects on the environment, having regard to, among other things: (i) the nature of the discharge and the sensitivity of the receiving environment to adverse effects; (ii) the financial implications, and the effect on the environment, of that option when compared with other options; and (iii) the current stage of technical knowledge and the likelihood that the option can be successfully applied.'

\section{(ii) Institutions for Policy Making and Environmental Quality Standards}

All provincial acts retain the institutional building blocks first introduced by the PEPO 1983, providing for the institution of the Environmental Protection Council and the Environmental Protection Agency, albeit that there are differences in their respective

\footnotetext{
${ }^{37}$ For a succinct account of the impact of the $18^{\text {th }}$ Amendment on environmental governance, see Rafay Alam, Situational Analysis of National Environmental Laws and Policies, Non-Compliance of these Laws, Resource Efficiency Issues and Gaps in Implementation and Enforcement (WWF-Pakistan, 2018)

38 Section 2(i) of PEPA 1997 defines "adverse environmental effects" as "impairment of, or damage to, the environment and includes - (a) impairment of, or damage to, human health and safety or to biodiversity or property; (b) pollution; and (c) any adverse environmental effect as may be specified in the regulations".
}

${ }^{39}$ Section 2(d) of the KPK Act. This is likely to restrict the ability of NGOs or persons acting in the public interest to use the act to bring polluters to justice..

40 Section 2 (h) of the KPK Act.

${ }^{41}$ Section 2(l) of the KPK Act. 
memberships and some variation in their functions. For instance, the KPK Act reduces the number of non-official members of the Council to 10, the Balochistan Act to six. All other environmental protection laws retain the original number of 25 non-official members.

The difference with the potentially most serious impact on environmental protection is the possibility for provincial departures from the National Environmental Quality Standards. With the exception of the Balochistan Act, all other provincial acts refer not to the national but to their respective provincial Environmental Quality Standards ${ }^{42}$. There is thus a possibility of different environmental quality standards across the country, a situation which could trigger a race to the bottom if these standards were ever fully enforced. Both the Sindh and the KPK Acts aim to reduce this risk, adding to the functions of their respective environmental protection councils the duty to "deal with inter-provincial and federal-provincial issues, and liaise and coordinate with other Provinces through appropriate inter-provincial forums regarding formulation and implementation of standards and policies relating to environmental matters with an inter-provincial impact". ${ }^{43}$ The Indian experience suggests that even in a scenario where environmental quality standards are uniform across the whole country, a state that enforces these standards less forcefully attracts more industries. ${ }^{44}$ In the current set-up, no central institution or ministry exists that is competent and empowered to determine National Environmental Quality Standards that would be binding on the provinces. The ability of provinces to determine their own provincial environmental quality standards could, in the long run, result in these standards being progressively lowered in order to retain or attract investment, as has happened in India in the case of differential enforcement of environmental law.

\section{Environmental Impact Assessment}

Other significant differences between provinces relate to environmental impact assessments. Reflecting its geology, the Balochistan Act prohibits the award of concessions for the extraction of minerals without consultation and approval of the Government of Balochistan and the EPA. Both the Balochistan and the KPK Act contain new provisions on Strategic Environmental Assessment, which are missing from the other environmental protection acts. Section 12 (1) of the KPK Act provides that

Government may ask to carry out strategic environmental assessment, of all or any of the plan or policy given below:

(i) socio-economic development, industrial and agricultural development, urban and rural development;

\footnotetext{
42 The provincial environmental quality standards are formulated and enforced by the provincial Environmental Protection Agencies, see sections 6 of the Punjab, KPK, Sind and Balochistan Act.

${ }^{43}$ Section 4 (g) of the Sindh Act and section 4(iv) of the Balochistan Act. Only the Sindh Act refers to international environmental law, providing in section 4 (i) that the Environmental Protection Council is to "assist the Federal Government or Federal Agency in implementation and or administration of various provision of United Nation Convention on Laws on Seas, 1980 (UNCLOS) in coastal waters of the province”.

${ }^{44}$ Kattumuri, Ruth and Lovo, Stefania 'Decentralisation of environmental regulations in India' (2018) 53: 43 Economic and Political Weekly, 33.
} 
(ii) land use and water use management;

(iii) the exploitation of natural resources;

(iv) economic zones or industrial parks and estates;

(v) transport and infrastructure;

(vi) solid, municipal and industrial waste;

(vii)tourism;

(viii) any other plan or policy likely to have an adverse impact on environment; (ix) prevention of water pollution through improper sanitation and control flow of sanitation water into the rivers; and

(x) separate zones shall be specified for poultry and cattle farming and slaughtering houses.

(iv) Enforcement of Environmental Quality Standards

There are also a number of provincial variations with respect to the enforcement of environmental quality standards. The Sind Act does not any longer allow a polluter to escape prosecution on payment of a pollution charge. Instead, there is a blanket provision in section 11 (2) that "All persons, in industrial or commercial or other operations, shall ensure compliance with the Environmental Quality Standards for ambient air, drinking water, noise or any other Standards established under section $6(1)(g)(i)$; shall maintain monitoring records for such compliances; shall make available these records to the authorized person for inspection; and shall report or communicate the record to the Agency as required under any directions issued, notified or required under any rules and regulations." Under section 22(6) of the Sindh Act, a polluter can apply to the EPA for the offence to be compounded. The procedure for the process has been notified under the Sindh Environmental Protection (Composition [sic] of Offences and Payment of Administrative Penalty) Rules, 2014. All other environmental protection acts retain provisions allowing for pollution charges as had been provided for in the original PEPA 1997.

Both the Sindh Act, in section 14, and the Baluchistan Act, in section 19, have added extensive provisions dealing with the handling of hospital waste. In addition, section 18 of the Balochistan Act contains specific provisions dealing with the handling of electronic waste. Further, its section 22 prohibits, as the only province, the import to Balochistan of alien species and of living modified organisms without a permit. Potentially higher environmental standards of motor vehicles can be imposed under the Sindh Act. As the only provincial environmental act, its section 15 (3) states that "For ensuring compliance with the standards mentioned in sub-section (1), the Agency may direct that any manufacturer of motor vehicle or class of vehicles shall use such manufacturing standard or design or pollution control devices or other equipment or undergo such testing as may be prescribed." The Sindh Act is also the only one which tasks its Environmental Protection Agency to carry out environmental monitoring of all projects that had been subject to EII or EIA in order "to determine whether the actual environmental impact exceeds the level predicted in the assessment and whether the conditions of the approval are being complied with." 45

\footnotetext{
${ }^{45}$ Section 19 (1) Sindh Act.
} 
Rules and Regulations

Provinces are now in the process of issuing rules and regulations under their respective environmental protection acts. By way of example, under the Sindh Act, the provincial government has issued a number of detailed regulations, including the Sindh Hospital Waste Management Rules, 2014; the Sindh Environmental Protection Agency (Review of Initial Environmental Examination and Environmental Impact Assessment) Regulations, 2014; the Environmental Sample Rules, 2014; the Hazardous Substances Rules, 2014; the Sindh Environmental Industrial Waste Water, Effluent, Domestic Sewerage, Industrial Air Emission and Ambient Airs, Noise for Vehicles, Air Emissions for Vehicles and Drinking Quality Standards, 2015; the Sindh Environmental Protection (Composition [sic] of Offences and Payment of Administrative Penalty) Rules, 2014; the Sindh Environmental Protection Tribunal Rules, 2014; the Sindh Environmental Quality Standards (Certification of Environmental Laboratories) Regulations, 2014; the Sindh Prohibition of NonDegradable Plastic Products (Manufacturing, Sale and Usage) Rules, 2014; the Sindh Sustainable Development (Procedure and Utilization) Rules, 2014 and the Sindh Environmental Quality Standards (Self-Monitoring and Reporting by Industry) Rules, 2014.

Similar, but not identical, rules and regulations have been issued under the PEPA 1997 for the Islamabad capital territory, as well as under the respective Punjab, KPK and Baluchistan Acts, thereby deepening regulatory variation between regions and provinces. As of now, there has been no research on the impact of these regulatory variations on environmental conditions. Arguably, the reality of weak enforcement of environmental laws across Pakistan means that any variation in their scope and ambit will not have any discernable impact on the environment. Reviewing Pakistan's Environmental Tribunals

The Environmental Tribunal Rules, 1999 established two environmental tribunals, one in Lahore, with jurisdiction over the provinces of Punjab and KPK (formerly NWFP), and the other one in Karachi, with jurisdiction over the provinces of Sindh and Balochistan. In 2005, separate environmental tribunals were established for Balochistan and KPK. Until the appearance of provincial environmental protection acts between 2012 and 2014, all four tribunals had exclusive jurisdiction to hear cases under the PEPA 1997. With the emergence of distinct provincial protection acts, the four environmental tribunals now apply the different provincial environmental protection acts.

The reporting of judgements of environmental tribunals commenced in 2008. By the middle of 2019, a total of 63 judgements have been reported, all of them in the Civil Law Digest, a Pakistani law report, and all decided by the environmental tribunals in Karachi and Lahore with the Punjab Environmental Tribunal having decided the bulk of them. There are no reported judgements from the other provinces.

Global environmental governance requires not only international and multilateral laws and institutions but also national environmental framework laws, enforcement agencies and mechanisms for environmental dispute resolution. Reflecting these imperatives, 
both the international community ${ }^{46}$ as well as scholars have shown an increasing in the global environmental rule of law $^{47}$. Brian Preston has developed a useful checklist to evaluate and assess the status, functioning and impact of specialist environmental courts and tribunals ["ECTs"]. Drawing from a wide range of sources on the working of environmental courts and tribunals across the globe, Preston developed a set of twelve characteristics which he identifies as critical for their success:

(i) Status and Authority

(ii) Independent from Government and Impartial

(iii) Comprehensive and Centralized Jurisdiction

(iv) Judges and Members are Knowledgeable and Competent

(v) Operates as a Multi-Door Courthouse

(vi) Provides Access to Scientific and Technical Expertise

(vii) Facilitates Access to Justice

(viii) Achieves Just, Quick and Cheap Resolution of Disputes

(ix) Responsive to Environmental Problems and Relevant

(x) Develops Environmental Jurisprudence

(xi) Underlying Ethos and Mission

(xii) Flexible, Innovative and Provides Value-Adding Function

Preston's checklist provides a useful framework to review the role, function and impact of Pakistan's environmental tribunals. Given the focus on reported decisions, not all of the criteria can be discussed in equal depth.

(i) Status and Authority

The criteria of "Status and Authority" assesses ECTs on the basis of their reputation: do stakeholders, governments and the wider community recognize ECTs as the appropriate and legitimate form for resolving environmental disputes? Preston refers to the Dhaka Environmental Court in Bangladesh as an example of an ECT that is not recognised as an appropriate forum for the resolution of environmental matters: it lacks independence from the government and suffers from a long back-log of cases. In contrast, Sweden's environmental code vests its environmental courts with a comprehensive civil and administrative jurisdiction which in turn has resulted in a substantial caseload. As a result, Swedish ECT's are fully accepted by both NGOs and industries. $^{48}$

In Pakistan's legal landscape, environmental tribunals become rarely visible. Across all four provinces, there have been lengthy periods during which environmental tribunals were not functional because the government had not appointed its members. The newspaper coverage of environmental tribunals only ever refers to the fact that they rarely function. For example, in April 2014 the Dawn newspaper, a well-established national English newspaper, reported under the headline 'Environmental Tribunal not

\footnotetext{
${ }^{46}$ See for instance George Pring and Catherine Pring, Environmental Courts \& Tribunals. A Guide for Policy Makers (UNEP, 2016) and UNEP, Environmental Rule of Law. First Global Report (UNEP, 2019).

${ }^{47}$ Brian J. Preston, 'Characteristics of Successful Environmental Courts and Tribunals' (2014) 26 Journal of Environmental Law, 365.

${ }^{48}$ Preston, op. cit., 367, 368.
} 
working for 20 months' that after the end of the contract of its Chairperson Ms Ashraf Jahan, the Sindh government had not appointed a new Chairperson, nor had it extended the contract of the technical member, which had ended in July 2010, nor the contract of the other member, which had expired in June $2013^{49}$. As a result, the Sindh environmental tribunal had been non-functional for almost two years.

Similarly, in the period between 2005, when it was first established, and 2011, the KPK Environmental Tribunal was functional for only 27 out of 84 months ${ }^{50}$. Indeed, governmental reluctance to make environmental tribunals functional marred their performance from the time when they were first established. It took an Order of the Supreme Court, for the Lahore Environmental Tribunal to be established on 18 December 1999. However, though functional it heard cases only on Fridays from 10.30 am to $12.00 \mathrm{pm}$. Three months later, on 29 February 2000, the Environmental Tribunal became non-functional because its Chairperson retired. It took another writ petition and an Order of the Lahore High Court for the Federal Government to appoint another Chairperson on 17 July 2000. Jawad Hassan ${ }^{51}$, who had filed the writ petition to force the government to activate the Punjab Environmental Tribunal, observed that "However, the functioning of the Tribunal has continued to be impaired due to the difficulties with the building, staff, and the procedural rules and regulations. " 52 In the following decade, it was closed for eight months in 2006-7, for six months in 2009 and for more than a year from July 2011 until June 2012, had decided only 435 out of a total of 2800 cases and had recovered only $20 \%$ of the fines imposed. ${ }^{53}$

Conversely, the existing body of reported judgements decided by environmental tribunals indicates that during the periods when they do function, environmental tribunals do carry out their statutory duties. Data on the performance of the KPK Environmental Tribunal shows that in the months when it was functional, it had decided 400 out of a total 491 cases, with many fines against industries up-held. The authors conclude that "The role of Environmental Tribunal in KP for environmental protection, and prevention of pollution is praiseworthy in this regard." 54

Data on the case-load of the Punjab Environmental Tribunal indicates that apart from some interruptions, it has been functioning since June 2012. It was functional at time of the completion of this article at the end of $2019 .{ }^{55}$ During this period, records show that in the year of 2013 it received a total of 1786 complaints, private complaints and appeals and disposed 1059 of them. In the year 2014 the corresponding figures for complaints and disposal were respectively1917 and 992, for the year 2015 they were

\footnotetext{
${ }^{49}$ Ishaq Tanoli, 'Environmental Tribunal not working for 20 months' Dawn (Karachi 7 April 2014) https://www.dawn.com/news/1098211 (accessed on 5 July 2019)

${ }^{50}$ Zulfiqar Ali, Bushra Khan, Fazal Ghani and Atta-ur-Rahman, 'Environmental Tribunal: Evaluating its Status and Performance in Khyber Pakhtunkhwa' (2012) 36:1\&2 Journal of Science and Technology, 17-24, 21.

${ }^{51}$ Now Justice Jawad Hassan of the Lahore High Court.

52 Jawad Hassan, 'Country Report - Pakistan' (2001) 6 Asia Pacific Journal of Environmental Law 319, 323.

${ }^{53}$ Sonia Malik, 'Environmental Tribunal: Only 15\% of Cases Decided, 20\% of Fines Recovered' The Express

Tribune (Lahore 3 June 2012) https://tribune.com.pk/story/387884/environmental-tribunal-only-15-of-casesdecided-20-of-fines-recovered/ accessed 1 July 2019. Additional reasons cited were the old age of the

Chairpersons and the Environmental Tribunal's view that PEPA 1997 was too strict and that it was sufficient to issue a warning.

${ }^{54}$ Zulfiqar Ali et. al., op. cit., 23.

${ }^{55}$ On file with the author.
} 
respectively 1418 and 691, for the year 2016 they were respectively 1003 and 1066 and, finally, for the year 2017 there were a total of 321 complaints, private complaints and appeals and 322 disposal of cases. Since 2012, the longest interruption in the functioning of the Punjab Environmental Tribunal lasted from August 2017 to January 2018: during this period no cases were disposed of and hence the disposal rate for 2017 is much lower than that for previous years.

Arguably, the low visibility and lack of publicity of the work of Pakistan's environmental tribunals in the media and in the law reports makes it more difficult for them to enhance their status and authority within Pakistan's legal system. Writing in 2012, the Chairperson of the Sindh Environmental Tribunal stated that in her experience increased media coverage had enhanced its visibility and use as a gateway to access to environmental justice for the poor:

"In Sindh the Tribunal started functioning in the present manner for the first time [July 2009]; therefor, its proceedings received much media coverage, adding to the public awareness in this regard. Resultantly, many people belonging to the poor class in our society came forward to agitate their environmental issues before the Tribunal. But this coverage was gradually discontinued due to the pressure of influential industrialists facing trial before the Tribunal." 56

Ashraf Jahan's experience suggests that there are no inherent limits to environmental tribunals becoming better known as legal gateways for access to environmental justice. Equally, Jahan's observations demonstrate that at least in Karachi and Sindh in 2012, powerful industrialists were able to silence media coverage of the working of the Sindh Environmental Tribunal.

The low visibility of environmental tribunals can be contrasted with the prestige and indeed glamour attached to the upper echelons of Pakistan's hierarchy of courts. Aptly named the "superior courts", the provincial high courts and the Supreme Court host the cream of the legal profession, of social and environmental activists and of publicinterest minded judges, all joined together in the endeavor of producing innovative judgments on environmental matters, reports of judicial commissions and conference papers. ${ }^{57}$ It is at this level that many of Brian Preston's characteristics resonate and that Pakistani environmental law connects with the international networks of NGOs and academia. Arguably, for the status and authority of Pakistan's environmental tribunals to increase will require not just an expansion of their jurisdiction and powers, but also a bigger share of the limelight and publicity enjoyed by environmental public interest litigation.

\footnotetext{
${ }^{56}$ Jahan Ashraf [now Justice Jahan Ashraf of the Sindh High Court], 'Functioning of Environmental Protection Tribunals - A First Hand Experience', conference paper delivered at the South Asia Conference on Environmental Justice, $24^{\text {th }}$ to $25^{\text {th }}$ March 2012, Bhurban, Pakistan (on file with the author).

${ }^{57}$ Parvez Hassan, Resolving Environmental Disputes in Pakistan: The Role of Judicial Commissions (Lahore, 2018)
} 
According to Preston, ECTs that are independent tend to be more successful. Preston stresses that independence comprises not just independence from the other two branches of government but also from other external influences ${ }^{58}$ Further, ECTs should not show any bias or conflict of interest, meaning that they should be impartial. Security of tenure plays an important part in determining the degree of independence and impartiality of an ECT. Without the tenure of its judges or members secure, there must be doubts about a court's or tribunal's independence ${ }^{59}$.

In respect of its legal status, Pakistan's environmental tribunal can be considered independent. Section 21 PEPA 1997 provides that the proceedings before the Environmental Tribunal are judicial proceedings within the meaning of sections 193 (Punishment for false evidence) and 228 (Intentional insult or interruption to public servant sitting in judicial proceeding) of the Pakistan Penal Code, 1860, and the Tribunals are deemed to be courts for the purposes of sections 480 (Procedure in certain cases of contempt) and 482 (Procedure where Court considers that case should not be dealt with under Section 480) of the Code of Criminal Procedure, 1898. In the exercise of their criminal jurisdiction, the Tribunals are vested with powers of the Court of Sessions under the Criminal Procedure Code. Identical provisions can be found in the Sindh, KPK and Balochistan Act.

Whenever they do function, proceedings before Pakistani environmental tribunals are considered judicial proceedings. The more difficult question is to identify the reasons for the lengthy periods when environmental tribunals do not or have not functioned. Whilst the government cannot directly interfere with the work of an environmental tribunal, by not appointing its members, it can prevent it from performing its statutory function of trying, convicting and sentencing those successfully prosecuted for environmental offences. As far as independence is concerned, Ms Ashraf Jahan, at the time the Chairperson of the Karachi Environmental Tribunal, observed that in her experience both industries as well as governmental entities complied with the Orders of Sindh Environmental Tribunal. ${ }^{60}$

\section{(iii) Comprehensive and Centralized Jurisdiction}

Preston finds that the more comprehensive its jurisdiction with respect to coverage of matters and disputes arising under all of the environmental laws of the land, the more successful the ECT. ${ }^{61}$ Comprehensive jurisdiction enabled ECTs to make a holistic contribution to environmental governance. Preston lists jurisdiction over civil enforcement, damages action, judicial review, merit review of administrative actions and, finally, criminal action as forming part of such a comprehensive jurisdiction. ${ }^{62}$

As could be seen further above, the jurisdiction Pakistan's environmental tribunals is much more limited. Being focused on imposing criminal sanctions on polluters, not only narrows the jurisdiction of environmental tribunals, but also introduces the

\footnotetext{
58 Preston, op. cit., 369.

${ }^{59}$ Preston, op. cit., 370.

${ }^{60}$ Jahan, op. cit., 2.

${ }^{61}$ Preston, op. cit., 372.

62 Ibdi., 373.
} 
procedural safeguards and evidential standards of criminal trials to the adjudication of environmental disputes. If it was otherwise "the accused who is a favourite child of law would be prejudiced." 63 The reported judgements decided by Pakistani environmental tribunals demonstrate that many of those accused of environmental offences secure acquittals because the evidence adduced by the prosecution was found to be unsound, had been improperly procured or because the prosecution had acted unlawfully.

Two judgements illustrate the impact of the procedural standards of criminal law on actions against those accused of environmental offences ${ }^{64}$.

In Director General, PA vs Raees-ul-Hassan, CEO, Habib Sugar Mills 2012 CLD 1696 the EPA had filed a complaint against a sugar mill for exceeding the National Environmental Quality Standards in respect of a number of effluents and discharges under section 11 PEPA 1997. The Karachi Environmental Tribunal ["KET"] observed that "It is established principle of law that the prosecution has to prove its own case independently beyond any shadow of reasonable doubt." [para 21] The KET found that the EPA had not complied with the correct procedure for the collection of samples, as stipulated under the Environmental Samples Rules, 2001 and that it could not be shown that the laboratory that examined the samples had been properly certified ${ }^{65}$. Ms Ashraf Jahan, the Chairperson, acquitted the accused CEO of the sugar mill because the EPA had not been able to prove the charge. Airing her dissatisfaction, Ms Jahan also ordered the Sindh government to take action against EPA officials as well as the laboratory:

31. It is relevant to mention here that while prosecuting the present respondent Environmental Protection Agency, Sindh Officials and PRD Lab authorities have failed to discharge their duties in accordance with law and their attitude was very casual and unprofessional. While taking note of this aspect of the case and our findings in this regard we deem it appropriate to make following observations in this case.

(i) Secretary, Environment and Alternative Energy Department may probe into the matter and examine the conduct of Environmental Protection Agency, Sindh, officials due to whose negligence sample could not be delivered to the laboratory within forty-eight hours. Simultaneously disciplinary action under Sindh Civil Servant (Efficiency and Discipline) Rules, 1973 may be taken against the officials responsible for violating the Environmental Sample Rules, 2011, not taking timely action against the violators as per procedure provided under the law and then preparing a defective case.

(ii) Suitable action under regulation 14 of The National Environmental Quality Standards (Certification of Environmental Laboratories) Regulation, 2000 may be taken against the concerned Laboratory in respect of non-

\footnotetext{
${ }^{63}$ Afzaal Ahmed Khan vs. DG EPA 2015 CLD 57, para. 7.

${ }^{64}$ See also DG EPA vs. Shabbir Ahmed 2012 CLD 2032, DG, EPA vs. Smail H. Zakaria, CEO 2011 CLD 1253, DG EPA vs. Farooq Gulzar 2013 CLD 16 and DG EPA Sindh vs. Mohsin Tabani 2012 CLD 2004.
}

${ }^{65}$ See the National Environmental Quality Standards (Environmental Laboratories Certification) Regulations 2000 . 
mentioning sample identification in certificate or analysis so that in future occurrence of such incidents may be avoided.

(iii) This order will not come in the way of Environmental Protection Agency, Sindh in case fresh proceedings are initiated against the respondent after fulfilling the legal requirement in accordance with law.

(iv) The Environmental Protection Agency, Sindh is also directed to investigate the cases comprehensively covering all types of pollution after taking composite samples. The relevant law and rules are to be followed strictly.

32. Copy of this judgment be sent to the Secretary, Environmental Alternative Energy Department. The compliance in respect of above observations shall be sent to this Tribunal within forty-five (45) days from the date of receiving the copy of judgment without fail.

In DG, EPA vs. Smail H. Zakaria, CEO 2011 CLD 1253 the Sindh Environmental Tribunal dismissed the evidence adduced by the EPA against a sugar mill as unreliable, because the Environmental Sample Rules 2001 had not been followed to the letter:

"However, at the same time in the light of discussion made above, as it is established that while dealing with this case Environmental Protection Agency, Sindh Officials and PRD Lab authorities have failed to perform their official duties diligently, in accordance with law. It appears that they remained oblivious of the legal consequences of their lethargic, causal and unprofessional conduct due to which the whole case of prosecution was seriously damaged."

A second source for acquittals is breaches of procedural safeguards and principles of natural justice by the prosecuting agency, the EPA. These include issuing orders without having heard the accused or posting, and later imposing, a Rule on its website which had not been issued as yet. This is a populous cluster and only a handful can be discussed here.

In DG, EPA, Sindh vs. Khawaja Anwar Majeed, CEO, Ansari Sugar Mills, Karachi 2011 CLD 857 the Sindh EPA had committed several procedural errors, including issuing an EPO without providing a personal hearing to the accused manager. The Karachi Environmental Tribunal ["KET"] dismissed the EPO, finding that "This conduct on the part of S.E.P.A. reflects their negligent, careless and non-serious attitude in performance of their official duties. " For the same reason the KET dismissed an EPO in DG EPA vs. Shabbir Ahmed 2012 CLD 2032. In Cantonment Board Sialkot vs. Provincial EPA 2019 CLD 555 residents had made a complaint against the Cantonment Board, administered by the Pakistani army, alleging that solid waste was dumped close to residential areas. An EPO was issued but dismissed by the Punjab Environmental Tribunal because the Cantonment Board had not been heard: 
"Environmental Protection Agency did not act properly and with due diligence. They could have easily heard the appellant. The appellant was not served at all. Audi Alteram Partem in simple words means 'hear the other side'. It is the most fundamental principle of Justice which states that no one ought to be judged without been given an opportunity to be heard." [para. 6]

In a number of cases, prosecutions were held to unlawful because the EPA officer who had issued the EPO was found to have exceeded their authority. In Lala Pak Bricks Kiln vs. DG, EPA 2016 CLD 913, as well as several other cases, complaints or EPOs were dismissed by the environmental tribunal because they had been issued under the authority of the District Officer and not an officer of Provincial EPA ${ }^{66}$. Similarly, a number of cases against companies failed because the EPA had not impleaded the Chief Executive but another senior manager of the company. ${ }^{67}$

In the recent case of Sindh EPA vs. Messrs Silver Textile 2019 CLD decided by the Sindh Environmental Tribunal, the Sindh EPO's investigative and procedural shortcomings drew strong rebuke from Justice (Retired) Sadiq Hussain Bhatti, Chairperson of the Sindh Environmental Tribunal ["SET"]. The Sindh EPA had made a complaint against a textile mill for operating without the required EIA approval and for refusing the Agency's Investigating Officer access to the premises. The SET dismissed the complaint and issued guidelines to the EPA which stressed the importance of conducting a full and thorough investigation before making a criminal complaint to the SET and discourage the SET from ordering the stoppage of a factory: "The harsh and penal act of stoppage of operational activities by the respondent should be resorted to in extreme cases as it would entail depriving of the workers of their butter and bread." [Para. $25(\mathrm{~g})]$

Finally, reference needs to be made to this cluster's most unusual case, a judgement concerned with the Punjab EPA imposing an administrative penalty on an oil exploration company. The company was accused of having commenced operations without the mandatory EIA. The Punjab EPO imposed an administrative penalty on the oil exploration company. As reported in Pakistan Oil Fields Pol House vs. DG EPA 2019 CLD 464, the Punjab EPA had posted a copy of Administrative Penalty Rules on their website, but these Rules had not as yet been notified and hence were not valid. The Punjab Environmental Tribunal held that:

"The placing of this material (un-notified rules) on official website of EPA is misleading and this practice of EPA is unlawful under section 31 of the Act which empowers the EPA to make rules by notification in the official Gazette for carrying out the purposes of this Act. EPA should refrain from such unlawful practice of placing the unapproved, un-notified Rules, Regulations and Policies on its official website in contravention of the statutory provision of section 31." [para. 6]

\footnotetext{
${ }^{66}$ See also District Officer (Environment) vs. Ghulam Farid Atta Chakki Unit 2016 CLD 778, Jalal Protien Farm vs. DG EPA 2016 CLD 1416, DG EPA vs. Sultan Industries Sialkot 2017 CLD 1117 and Shakarganj Ltd. vs. EPA, Punjab 2016 CLD 1439.

${ }^{67}$ See for instance DG, EPA vs. Fatima Sugar Mills Ltd 2016 CLD 1186 and Colony Sugar Mills vs. EPA, 2016 CLD 1271.
} 
PEPA 1997 aims to include technical expertise in the membership of the Environmental Tribunal. Whilst the qualification of the Chairperson is governed by PEPA 1997 and its provincial clones, the qualifications of the other two members is governed by the Environmental Tribunals (Procedure and Functions) Rules, 2008, which provide that

1. A Technical Member of the Tribunal shall be a person who has at least -

1. (a) A second class B. Sc. Engineering degree in Chemical, Civil, Public Health, Environmental or Industrial Engineering; or a second class M. Sc. Degree in Physics, Chemistry, Biology, Chemical Technology or Environmental Science; and

2. (b) seventeen years, experience in BPS-17 and above or equivalent relating to the field of any prescribed academic qualification.

Explanation: The experience prescribed in clause (b) shall be calculated after acquisition of the educational qualification prescribed in clause (a).

(2) The Legal Member of the Tribunal shall be a person who is or has been as is qualified for appointment as judge of the High Court.

In practice, a review of the reported judgements indicates that environmental tribunals are only rarely fully constituted. The majority of the reported judgements were decided by tribunals composed of only the Chairperson and one member. As a result, in the majority of reported judgements, environmental tribunals functioned without a Technical Member. Applying Preston's criteria, mainly on paper do Pakistan's environmental tribunal combine both legal and technical expertise. ${ }^{68}$

(v) Operates as a Multi-Door Courthouse

Preston observes that many successful ECTs offer court-annexed and other ADR services to parties reluctant to resort to litigation. As presently constituted, Pakistani environmental tribunals do not offer any ADR services. ${ }^{69}$ Confirming Preston's assessment of the usefulness of ADR in resolving environmental disputes, Chairperson Ashraf Jahan observes that the concept of pre-trial negotiations should be introduced in the proceedings before the environmental tribunals:

"Furthermore, in some of the cases the parties who appear before the tribunal already show willingness to fulfil the legal requirements. Hence in order to implement the Law in its true sprit it would be advisable if pre-trial negotiations were held before the tribunal and matters were disposed of at an early stage without entering into the lengthy process of trial. This would ultimately produce more effective, acceptable results and minimize undesirable or vexatious litigation."70

(vi) Provides Access to Scientific and Technical Expertise

\footnotetext{
${ }^{68}$ Preston, op. cit., 377.

${ }^{69}$ Preston, op. cit., 379.

70 Jahan, 5.
} 
Preston finds that resolving environmental disputes requires ECTs to address complex questions such as causation, damages and risk of environmental harm of a proposed development. ${ }^{71}$ With respect to their criminal jurisdiction, the reported judgements show that Pakistani environmental tribunals have not faced any need for additional scientific or technical expertise. Proceedings concerned with the issuance or refusal of issuance of EIA, however, frequently involve disagreements over science, such as the environmental impact of an activity. In several instances, Pakistani environmental tribunals disagreed with the EPA's scientific assessments. For instance, in United Ethanol Ltd. vs. EPA, Punjab 2015 CLD 1079, the appellants had installed a tyre pyrolysis plants. The EPA refused to approve the plant and instead issued an EPO for its closure. The factory owner appealed to the PET. The PET carefully considered and reviewed the scientific evidence, holding that

“(5) The pyrolysis state-of-art process plants work in closed loops and there is hardly any emission of concern from the plant if proper mitigation and housekeeping measures are implemented. The Basel Convention and WTO rules also consider recycling of scrap tyres as a better option than their use as tyre derived fuel.

(6) The appellants projects will be helpful to shift the focus from open burning, open dumping and land filling to an organized industrial activity involving less health and environmental hazard and will promote economic growth.

(7) It is to mention that waste tyres management is an international problem due to non-compaction and poor bio-degradability. Improper disposal of waste tyres is posing serious threat to public health, safety and the environment. It is well established that waste tyres become sources of breeding places of insects and rodents, crate fire hazards, leach toxin in soil and waste and build up issues of aesthetics.

(8) The appellants project will help to reduce/solve the above mentioned problems/issues and will provide a road map for sustainable/green solution to the problem." 72

\section{(vii) Facilitates Access to Justice}

Preston differentiates between substantive decisions of an ECT up-holding fundamental constitutional, statutory and human rights access to justice as well as its practice and procedures. ${ }^{73}$ PEPA 1997 limits access to tribunals to aggrieved persons, subject to notifying EPA of their intention to file a complaint.

Two contrasting judgement can be referred to. In the first, the Tribunal was intent to broaden access: In Syed Haroon Ahmed vs. Dadex Eternit Ltd. 2010 CLD 1555 the brother of the complainant had died of cancer allegedly caused by the Respondent-factory use of asbestos. When the brother of the deceased made his complaint, the company filed an

\footnotetext{
${ }^{71}$ Preston, op. cit., 381.

${ }^{72}$ In the event, the EPO was dismissed on procedural grounds: the relevant Advisory Committee had not considered the factory's EIA application.

${ }^{73}$ Preston, op. cit., 383.
} 
application for the dismissal of the complaint because the brother was not an aggrieved person. The Sindh Environmental Tribunal observed that not only was the complainant the deceased's brother but that the environmental concern was a matter of public interest, holding that

"Furthermore the issue of environmental hazard raised by the complainant seems to be an issue of public interest, in which case principle of aggrieved person cannot be strictly applied. Further for arguments' sake if it is presumed that there has been any procedural lapse in entertaining this complaint again it will be a question worth consideration whether such procedural lapse is incurable or fatal to the proceedings of this complaint or not. More so when the respondent has failed to show that due to such reason any prejudice has been caused to him particularly when as a general rule procedural provisions of law are directory in nature and not mandatory unless so provided by the Law." [para. 15]

In the second example, the Tribunal restricted access: in Shahbaz Ali Hussaini vs. Provincial EPA 2019 CLD 647 the Punjab Environmental Tribunal held that a local resident had no standing to oppose an Environmental Approval after the expiry of 30 days from its date. However, the Tribunal left open the option of an alternate remedy: the resident could file a private complaint if the concerned sugar mill violated the conditions of the Environmental Approval. ${ }^{74}$

In the account of her first-hand experiences, Chairperson Ashraf Jahan adds her own recommendations for increasing the impact of environmental tribunals, stating that all persons rather than just aggrieved persons should be allowed to make complaints. In addition, tribunals should be given suo moto powers in order to initiate proceedings against polluters themselves rather than having to wait for the EPA or an aggrieved person to make a complaint: "It will also help in removing the bottle neck procedures in the present law due to which many cases relating to environmental issues, no timely action is taken which results in aggravating the situation." 75

The restriction of locus standi to aggrieved persons under all of Pakistan's environmental protection acts ${ }^{76}$ could explain why there are only two judgements concerned with complaints filed by NGOs, namely Sumaira Awan, Secretary General vs. Government of Pakistan and others 2008 CLD 1185 and Shehri-CBE vs. Sindh Environmental Protection Agency 2010 CLD 859. With the exception of the KPK Act, PEPA 1997 and the other three provincial acts not only restrict standing but stipulate in section 10 that "Where the Environmental Protection Tribunal is satisfied that a complaint made to it under subsection (3) is false and vexatious to the knowledge of the complainant, it may, by an order, direct the complainant to pay to the person complained against such compensatory costs

\footnotetext{
${ }^{74}$ See also Faisal Iqbal vs. Environmental Protection Authority 2019 CLD 208.

75 Jahan, 4.

${ }^{76}$ With the Sindh Act adding a narrow definition of "aggrieved person" in Section 2(d) as

"a person whose legal right is violated by any act or omission or is directly and adversely affected by an order of any authority". In sharp contrast, Section 19 (b) of the India's Environment (Protection) Act 1986 gives standing to "any person" subject to a 60 days notification requirement. For a comprehensive and detailed comparison of Indian and Pakistani environmental law, see Rafay Alam and Sanjay Upadhyay, Shared Environmental Concerns between India and Pakistan (World Bank Policy Paper, 2014).
} 
which may extend to one hundred thousand rupees." Arguably, the fact that this provision does not feature in any of the reported judgement could be a reflection of its effectiveness.

\section{(viii) Achieves Just, Quick and Cheap Resolution of Disputes}

Given its purpose of preventing or mitigating environmental harm, ECTs that decide cases quickly must, according to Preston, be considered more successful. The Table appended to this article offers an overview of the length of time between the date of filing of a complaint and the date of a decision. The table suggests that the majority of complaints are decided within about 1.5 years, with the disposal rate having sped up more recently.

Whether decisions of Pakistan's environmental tribunals are just is a more difficult question to answer given that in the context of an environmental dispute an assessment of the justness of a decision is likely to differ between the losing and the winning party.

A cluster of ten judgements offer some glimpses of the elusive and contested idea of what is just and what is not in the context of disputes before environmental tribunals. All ten were decided by a fully constituted bench of three members: Chairperson, Technical Member and Legal Member. In all of them the Legal Member disagreed with the decision of the other two. In fact, in all but one, the Legal Member decided against and the other two members more favorably to the accused. ${ }^{77}$ Arguably, the conflicting decisions also reflect different conceptions of what is perceived to be just. Five of the judgements will be discussed. ${ }^{78}$

In DG EPA vs. Qasim Glass Bottles 2011 CLD 1024 a glass bottle factory was operating day in and night out in a residential area causing significant pollution. In response to a private complaint, the factory owner claimed that operations had been stopped because of gas supply and labour problems. The PET adjourned the case. The Legal Member disagreed with the adjournment because she found that the factory had only closed for three months for annual maintenance and that:

"It seems that respondent is playing hide and seek with the Tribunal and abusing the process of law. Whenever, Site Inspection was ordered to be conducted by this Tribunal, the respondent close the unit to avoid the Site Inspection. This behaviour has been practicing by the respondent since 2006. The Site Inspection reports sufficiently evident that due to the functioning of respondent unit, large number of inhabitance of the locality are suffering due to high noise, gaseous emissions like Nox and high heat in the locality. Therefore, relying upon all the above mentioned Site Inspection Report, which sufficiently connect the respondent with commission of offence under section 11 of PEP Act 1997 the respondent factory has to be closed permanently to safe the people from all types of environmental complications. To adjourn such cases for indefinite period will serve no purpose except to hang the sword permanently over the heads of sufferer i.e. inhabitants of the locality.

\footnotetext{
${ }^{77}$ In DG EPA vs. Hafeez Steel Mills 2011 CLD 1220 the majority sentenced the accused to a fine. Legal Member Gulzar disagreed, finding that the requirements of a criminal trial had not been complied with. ${ }^{78}$ For the other split decisions see Mian Muhammad Imran vs. Paramount Engineering Works 2011 CLD 1189 , Pakistan Mobile Communication vs. DG EPA 2011 CLD 1280, Abdul Hameed Poultry Farm vs. Pakistan Environmental Act (XXXIV of 1997) 2011 CLD 1103, Sardar Fakhar Imam vs. Taj Paper Mills 2011 CLD 1179 and DG EPA vs. Wi-Tribe 2011 CLD 1138.
} 
For the past pollution, respondent be charged with Rs.500,000 as fine to be deposited within one month of passing the order, failing which, the respondent Unit be sealed permanently by the Punjab Environmental Protection Agency."

In DG EPA vs. Telenor Company, Gharib Shah 2011 CLD 1067 the majority ordered the non-Pakistani to appear before the PET in person for the recalling of a bailable arrest warrant. The Legal Member disagreed, holding that the law allowed for the personal attendance of the accused to be dispensed with and "as he is foreigner and of course due to the social and political situation prevailing in the country now-a-days, the travelling of foreigner is not safe; especially in public places. ” In DG EPA vs. Walid Junaid Steel Mills 2011 CLD 1168 the majority of the PET dismissed the complaint made by the Punjab EPA against the owner of a polluting steel mill, because the mill was not any longer in operation. The Legal Member disagreed, stating that the closure of the steel mill should not lead to the dismissal of the charges under PEPO 1997.

In DG EPA vs. Syed Mansoor Ali Shah Poultry Farm 2011 CLD 1155 the majority approved the status report of the Respondent poultry farm, which showed that all was well: there were burial pits for dead birds, a solid waste storage room and a soakage pit for liquid waste disposal. Legal Member Ms Gulzar Butt did not disagree with the findings of the status report but considered, in addition, the location of the poultry farm. According to the Site Inspection Report of the EPA the "respondent unit is situated in Rawal Lake catchment area and closer to natural streams in the area and residential area of the village." Ms Gulzar Butt found that the guidelines regarding poultry farms required a distance of 500 meters from human settlements and ordered "That is why distance is required to be measured specifically to arrive at just and proper decision and without these measurements the complaint may not be disposed of."79

From an environmental perspective, the orders of the Legal Member are more environmentally just. In turn, this demonstrates that despite the straightjacket of narrow jurisdiction, tribunals can side with environmental concerns and objectives, if they are so minded or tasked.

(ix) Responsive to Environmental Problems and Relevant

Preston states that "successful ECTs are better able to address the pressing, pervasive and pernicious environmental problems that confront society (such as climate change and loss of biodiversity)." $" 80$ Lacking suo moto powers, being mostly concerned with questions of criminal liability and with their dockets determined by the types of complaints made and appeals filed, Pakistan's environmental tribunals have only limited scope for responsiveness. This has not prevented the Punjab Environmental Tribunal from embarking on wide-ranging and thoughtful considerations of principles of international environmental law in its judgements. In Pepsi Cola International (Private) Limited vs. Punjab EPA 2018 CLD 1429 Chairperson Shazib Saeed had to decide whether the EPA could order an air

\footnotetext{
79 The same scenario played out in DG EPA vs. Gulzareen Poultry Farm 2011 CLD 1209.

${ }^{80}$ Preston, op. cit., 387.
} 
monitoring device to be installed inside the premises of a factory. The Punjab Environmental Tribunal up-held the EPO, reasoning that

a. if the SMART scheme could compel a factory to report its emissions to the EPA in real the ime there was no legal reason why the EPA could not order a factory to install a monitoring device inside its premises;

b. reviewing a number of sources and principles of international environmental law and sustainable development the Chairperson fastened on the polluter pays principle to decide that it was within the power of the EPA to take preventive measures to control pollution, including issuing the EPO at issue.

Statutes are always the subjects of judicial interpretation. Pepsi Cola International (Private) Limited vs. Punjab EPA demonstrates the impact of knowledge of environmental law and commitment to environmental values on the outcome of cases. As with decisions discussed in the context of justness, Pepsi Cola International (Private) Limited is also a split decision, with the Member (General), Mr Muzaffar Mahmood, interpreting the relevant sections of PEPA and the Environmental Sample Rules, 2001 more restrictively, holding that they not authorize EPA to install monitoring devices inside factories ${ }^{81}$ Relying on section 20 (4) PEPA 1997, which provides that if there is a difference of opinion between the Chairperson and the Member, the opinion of the former prevails, Chairperson Saeed could decide for the Tribunal and, arguably, for the environment.

Develops Environmental Jurisprudence

Preston argues that successful environmental tribunals have a substantial case-load which enables them to develop environmental jurisprudence. ${ }^{82}$ As can be expected, the jurisprudence developed by Pakistan's environmental tribunals is confined to the areas of law within their jurisdiction. Reviewing the body of case-law under this heading, this section considers the clusters of cases involving successful prosecutions and successful EPOs. In the first group are the judgements that convict polluters, in the second are cases concerned with environmental impact assessments.

\section{a. Convictions of Polluters and Up-Holding of EPOs}

Out of total of 63 reported judgments, only seven confirmed an EPO or convicted the accused. A review of these seven "successful" judgements is therefore useful if not imperative. ${ }^{83}$

The most recent of these seven decisions is concerned with pollution caused by a tannery. In 2010, the EPA had issued EPOs against 55 tanneries situated in Sialkot, giving them six months to either install an effluent treatment plant or to stop operations. The tanneries did not comply with the EPO and a non-compliance report was filed with the Federal Environmental Tribunal in February 2012. After 46 adjournments, the Respondent tannery was charged in 2018. In DG EPA vs. Sheikh Yousaf, 2019 CLD 155 the Respondent pleaded guilty, admitting that "His tannery was found causing pollution to the environment creating

\footnotetext{
${ }^{81}$ Section 6(1)(g) (i) Punjab EPA 1997 and section 7(1) Environmental Sample Rules, 2001.

82 Ibid., 388.

${ }^{83}$ This cluster includes Coca Cola Beverages (Pakistan) Ltd. vs. DG EPA 2012 CLD 1887, discussed in the previous section.
} 
adverse effect by discharging of untreated effluent and waste water exceeding the NEQS", that "There was no system installed for proper disposal of waste water"; that "he failed to comply with the directions of EPO" but that his tannery was not any longer in operation. A site inspection ordered by Chairperson Shazib Saeed revealed that the tannery was very much in operation. The accused was sentenced to a fine of Rs 500,000, about $£ 2,500$.

In the same year, in Messrs United Feeds (PVT) Ltd. Vs. Provincial Environmental Agency 2018 CLD 1454, the principal of the Muslim College in Multan had filed a private complaint against a rice mill that had been converted to a factory producing chicken feed. The principal alleged that "it was using animal intestines, creating havoc, bad smell amongst the 2000 students of the college and request was made to initiate action under the environmental law against the unit." An investigation by the EPA revealed that the unit was indeed producing chicken feed, and in the process "huge volume of smell in the form of obnoxious steam is released into the ambit air making it polluted and degrading its quality to the extent of unfit for breathing for 2000 students and college management, directly suffering from tile polluted air." [para 3]

Referring to a wide range of precedents from India and Pakistan and using google maps, the Punjab Environmental Tribunal up-held the EPO which had ordered the factory to conduct an EIA: "Unit of the appellant has to go through the nature's first man-made check post of IEE and EIA. This is mandatory and cannot be avoided." [para. 18] However, as above, during the pendency of the EIA process, the unit was allowed to continue to operate.

A poultry farm housing 50,000 consumers of chicken feed was the subject of EPO enforcement proceedings before the Punjab Environmental Tribunal in DG EPA vs. Messrs RB Poultry Farm No. 12018 CLD 1484. Over the course of six years, the farm's owner had managed to evade the EPA's efforts to get him to comply with an EPO to clean up the site. After a criminal trial, the PET found the farm's guilty under PEPA 1997 to a total fine of Rs 500,000. Chairperson Shazib Saeed added a reference to section 67 Pakistan Penal Code 1860 to the judgment. It provides for imprisonment for non-payment of a fine.

Listed on the stock exchange, Packages Ltd is one of the largest companies in Pakistan. In Packages Limited vs. Environmental Protection Agency, Government of The Punjab 2018 CLD 1178 one of its industrial units had been discharging waste water into open drains for a number of years, in breach of an EPO issued by the Punjab EPA as far back as 2009. Eventually a local resident made a complaint against the factory to the Punjab Environmental Tribunal. Rather than complying with the subsequently issued EPO, Packages Ltd. filed an appeal with the Punjab Environmental Tribunal petitioning for the dismissal of the EPO. The Punjab Environmental Tribunal rejected the appeal and upheld the EPO, finding that the appellant's unit, despite a lapse of about nine years, had failed to control its effluents as mentioned in the EPO.

Finally, in Sindh Particle Board Mills Ltd. vs. EPA 2011 CLD 1271 the owner of a chipboard factory appealed against an EPO that ordered the closure of the factory. As mentioned in the judgement, the conditions inside the factory were so bad that even the EPA "survey team was facing lot of uneasiness in carrying the inspection due to high intensity of emission of fine particles." [para 15] The Sindh Environmental Tribunal upheld the validity of the EPO. 
Despite these recent successes, many prosecutions fail. The outcome is better in cases of alleged violations of IEE and EIA requirements. Here, environmental tribunals regularly order for EIAs to be submitted, albeit that they do not order the stoppage of the polluting activity until the EIA has been issued, save one recent exception discussed below.

The case of Sumaira Awan, Secretary General vs. Government of Pakistan and others 2008 CLD 1185 involved an NGO, the Eco Green Society of Pakistan, which made a complaint to the Punjab Environmental Tribunal, alleging that two under-passes, already under construction, were built without the mandatory EIA having been obtained. One thousand mature trees had already been cut. The respondents were governmental entities as well as a commercial contractor. According to the respondents, no EIA was required and in any event, the case should be dismissed because the under-passes had already been constructed: there was nothing more to be done.

The Punjab Environmental Tribunal observed that, first, in their criminal jurisdiction it very much mattered whether the respondents had committed the crime of not complying with an EIA requirement under section 12 PEPA. The crime did not disappear simply because the construction of the under-pass was complete. Second, the cutting of 1000 trees had an obvious "Adverse Environmental Effect" and hence attracted the EIA requirement. Third, the Punjab Environmental Tribunal ordered the government to prepare a collective EIA for all future transportation infrastructure projects planned for the next 20 years, rather than submitting EIAs for individual projects. With respect to the criminal liability, the PET decided not to punish the respondents not because they were not guilty but because

"... this Tribunal, in the larger interest of the public and to promote of the Environmental Law, especially with reference to preamble of PEPA, 1997 is more interested in promotion of sustainable development of Environment than the determining accusation of the respondents alleged in the complaint."

In contrast, a fine was imposed for breach of an EIA requirement in Lafarge Pakistan Cement Factory Ltd. Vs DG EPA 2011 CLD 1295 where a cement factory had commenced operations without the legally mandated Environmental Impact Assessment. Following a private complaint, the owner of the factory was found guilty of an offence under section 12 PEPA 1997 and fined.

In Shehri-CBE vs. Sindh EPA 2010 CLD 859 an NGO had made a complaint alleging that EIA requirements had been ignored in the construction of a major transportation project in Karachi. The Sindh Environmental Tribunal agreed with the NGO but rather than ordering the construction works to be stopped, it ordered that

"We deem it just and equitable to allow such construction process on account of welfare of general public, with the direction to District Government to submit EIA report within one month. However, failure in submission within time will disentitle them from continuing with the construction work of their project."

Finally, in Sarfraz Khan vs. Province of Sind, 2010 CLD 1507, residents made a complaint against a factory located in a residential area that produced ice and had expanded its 
operations in the course of several years. The Karachi Environmental Tribunal ["KET"] took note of the fact that lives had already been lost due to leakage of ammonia gas in residential areas. Referring to Shehla Zia $v$. WAPDA, the precautionary principle, and the Bhopal gas leak of 1984, the KET found that the ice factory was indeed run in a residential area but that according to the Sindh EPA its emissions did not breach the NEQS. The KET could only advise the municipal government to order its relocation.

The 2018 decision of the Punjab Environmental Tribunal in Haji Muhammad Ismail Proprietor of Muhamad Ismail Construction Company vs. DG EPA 1019 CLD 80 was concerned with an asphalt plant operated since 2010. The plant had been set up without an EIA and was now attracting complaints from local residents unhappy with the clouds of black smoke emitted by the plant. Having ignored several EPOs instructing him to control excessive smoke, the EPA sealed the plant. It was then that the owner of plant appealed to the Punjab Environmental Tribunal [PET"] for the EPO to be overturned. The PET did not budge, referring to the precautionary principle "which requires the relevant agency and to take immediate steps to prevent harm or danger to the environment" and confirming the legality of the EPA's sealing of the plant until the satisfactory completion of the EIA process, that had now been ordered to be conducted.

\section{(xi) Underlying Ethos and Mission}

According to Preston, successful ECTs often adopt a statement of purpose, such as the promotion of sustainable development and the maintenance of ecological processes, to guide their operations and to provide a general benchmark to measure their progress. ${ }^{84}$ Pakistan's environmental tribunals have not formulated a mission statement per se but the preamble of PEPA 1997 could serve as their statement of purpose, namely to protect, conserve, rehabilitate and improve the environment, to prevent and control pollution, and to promote sustainable development. As could be seen in the previous sections, environmental tribunals are increasingly referring to the principles contained in the preamble of PEPA 1997, as well as those developed in the fields of international environmental law and sustainable development.

\section{(xii) Flexible, Innovative and Provides Value-Adding Function}

According to Preston, successful ECTs add value to administrative decision-making by formulating and applying non-binding principles and formulating new procedures that promote flexibility and innovation. ${ }^{85}$

Given their narrow jurisdiction, Pakistani environmental tribunals are limited in their ability to be flexible and innovative. For this to happen, Pakistani environmental law itself would have to adapt and re-focus, for instance by paying more attention to civil law remedies and approaches, as is the case with the National Green Tribunal in India. ${ }^{86}$ Nevertheless, the previous sections have demonstrated that even within their narrow

\footnotetext{
${ }^{84}$ Preston, op. cit., 390.

${ }^{85}$ Preston, op. cit., 390.

${ }^{86}$ Gitanjali Nain Gill, 'A Green Tribunal for India' (2010) 22 Journal of Environmental Law 461; Gitanjali Nain Gill, 'Access to Environmental Justice in India with Special Reference to National Green Tribunal' (2013) 6:4 OIDA International Journal of Sustainable Development 25.
} 
jurisdictional framework, Pakistan's environmental tribunal have adopted approaches in the interpretation of statutes that have added environmental values to their decisions.

\section{Conclusion}

Commenting on the reported judgements of Pakistan's environmental tribunals, the 2013 ADB Report on Development of Environmental Laws and Jurisprudence in Pakistan painted a bleak picture: in their decisions environmental tribunals failed to address environmental concerns in a comprehensive manner, placed a narrow reliance on PEPA 1997 rather than incorporating references to principles of international environmental law, they lacked detailed reasoning for their decisions and, finally, they did not consider the case-law of the high courts and the Supreme Court: "Even PEPA is viewed narrowly, without expanding its boundaries and interpreting it in a holistic and vibrant manner for the cause of the environment." 87 The Report's authors identified the lack of proper environmental law training of the environmental tribunal members as a contributing factor for their weak performance.

Six years on, it is possible to revise this critical assessment for the better. The review of 63 reported judgements demonstrates that Pakistan's environmental tribunals are becoming more environmentally conscious and focussed, resulting in an increase in the number of successful prosecutions and confirmations of EPOs for compliance with mandatory EIA processes. Many of the recent judgements are well reasoned and do rely on a wide range of sources, including the decisions of superior courts and principles of international law and sustainable development. Several of the recent judgements handed down by the Punjab Environmental Tribunal deserve to be described as vibrant and holistic.

Despite this positive trend, the reported judgments of Pakistan's environmental tribunals also reveal gaps and deficiencies in the structure and implementation of Pakistan's environmental framework laws. From their very inception in 1983 onwards, Pakistan's environmental laws have been conceived as criminal laws, policed by environmental protection agencies and with the accused being tried by specialist environmental tribunals. Post-2010 and the $18^{\text {th }}$ Amendment, provincial governments have missed the opportunity to reconsider and review the structure and framework of environmental protection laws holistically and in light of the experiences gained from the failure to implement and enforce PEPA 1997. Instead, all provincial environmental protection laws follow and adopt the basic structure of PEPA $1997 .{ }^{88}$

The review of the reported judgements of the Punjab and the Sindh environmental tribunals demonstrates that the procedural and evidential requirements of a criminal trial are difficult to meet. Many prosecutions fail because of flaws in the way the EPA had gathered the evidence or conducted the investigation. As pointed out by Rosencranz and Upadhyay in their criticism of criminal law approaches to environmental protection in India, criminal prosecution focuses on awarding penal sanctions rather than preventing pollution and requires more stringent procedural safeguards than civil proceedings: "The problems in pursing criminal prosecution of environmental offenders also give rise to reluctance on the part of regulatory agencies to

\footnotetext{
${ }^{87}$ Saima, op. cit., 14.

${ }^{88}$ Pakistan is not alone in persisting with a command-and-control approach widely credited as less effective than other approaches, such as economic incentives, see Daniel H. Cole, 'Explaining the Persistence of "Commandand-Control” in the US' in: (2017) University of Indiana Environmental Law Legal Studies Research Paper

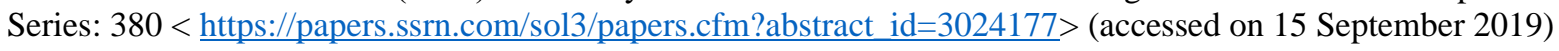


pursue more difficult cases. " 89 As could be seen in the first part of this article, economic approaches to environmental protection, such as SMART and civil or administrative penalties, have not been developed and actioned.

The judgements also suggest that not all can be blamed on the criminal law approach of Pakistan's environmental laws. In a number of cases a more environmentally friendly outcome would have been possible - as can be discerned from the judgements decided by majorities and even in those cases resulting in convictions tribunals never took advantage of the full range of available penal sanctions. There is not a single judgement which ordered the polluter to pay a fine in relation to the monetary benefit derived from the polluting activities, nor are there any cases of daily fines or orders for the restoration of polluted waters or soil. There are no cases concerning repeat offenders and thus no sentences of imprisonment. Even when EIA requirements are violated, factories are allowed to continue with their operations pending the issuance of an EIA. At present, the threat of a low monetary fine on conviction is unlikely to deter industries from violating environmental protection laws.

Finally, the judgments indicate that the existing environmental laws do not do enough to provide access to environmental justice. The standing provisions in all five environmental protection acts are restricted to aggrieved persons, thereby preventing NGOs and concerned citizens from making complaints. Lack of access curtails the potential role of environmental tribunals in environmental governance: it is local concerns such as poultry farms and sugar mills rather than substantial industrial pollution or the air pollution caused by countless brick kilns that dominate the case-law. Better access to environmental tribunals would allow NGOs and concerned citizens to develop litigation strategies for the enhanced enforcement of environmental protection laws. As it stands, defenders of the environment continue to be dependent on the willingness of the Supreme Court and the high courts to allow for environmental public interest litigation. It is the latter that meets more fully Brian Preston's twelve characteristics of successful ECTs, but as this article has demonstrated, there is every chance that Pakistan's environmental tribunals will catch up.

\footnotetext{
${ }^{89}$ Amin Rosencranz and Videh Upadhyay, 'Some Suggestions and Recommendations towards a Model State Pollution Control Board (SPCB) in India’ (2011) 1 Environmental Law \& Practice Review 106, 113.
} 


\section{BIBLIOGRAPHY}

\section{A. Cases}

Abdul Ghani vs. Raiwind Chemical (Pvt.) Ltd. 2016 CLD 1400 (SET)

Afzaal Ahmed Khan vs. DG EPA,2015 CLD 57 (PET)

Big Birds Poultry Breeders (Pvt.) Ltd. vs. DG EPA 2017 CLD 557 (PET)

Cantonment Board Sialkot vs. Provincial EPA 2019 CLD 555 (PET)

Coca Cola Beverages (Pakistan) Ltd. vs. DG EPA 2012 CLD 1887 (SET)

Colony Sugar Mills vs. EPA 2016 CLD 1271 (PET)

Colony Sugar Mills vs. EPA 2016 CLD 1429 (PET)

DG EPA vs. Abdul Hameed Poultry Farm 2011 CLD 1103 (PET)

DG EPA vs. Abdul Khaliq 2012 CLD 1848 (SET)

DG EPA vs. Ashraf Sugar Mills Ltd. 2016 CLD 1628 (PET)

DG EPA vs. Farooq Gulzar 2013 CLD 16 (SET)

DG EPA vs. Fatima Sugar Mills Ltd 2016 CLD 1186 (PET)

DG EPA vs. Gulzareen Poultry Farm 2011 CLD 1209 (PET)

DG EPA vs. Hafeez. Steel Mills 2011 CLD 1220 (PET)

DG EPA vs. Hassan Ice Factory 2019 CLD 137 (PET)

DG EPA vs. Khawaja Anwar Majeed, CEO, Ansari Sugar Mills 2011 CLD 857 (SET)

DG EPA vs. Mohsin Tabani, CEO of TMK Sugar Mills 2012 CLD 2004 (SET)

DG EPA vs. Multan Industrial Estate 2011 CLD 1325 (PET)

DG EPA vs. Pak Packages 2018 CLD 895 (PET)

DG EPA vs. Qasim Glass Bottles 2011 CLD 1024 (PET)

DG, EPA vs. Raees-ul-Hassan et. al. 2012 CLD 1696 (SET)

DG EPA vs. RB Poultry Farm No. 12018 CLD 1484 (PET)

DG EPA vs. Shabbir Ahmed 2012 CLD 2032 (SET)

DG EPA vs. Shaheen Foundry Okara 2011 CLD 1373 (PET)

DG EPA vs. Sheikh Yousaf 2019 CLD 155 (PET)

DG EPA vs. Sikandar Plastic Recycling Unit 2019 CLD 907 (PET)

$D G, E P A$ vs. Smail H. Zakaria, CEO 2011 CLD 1253 (SET)

DG EPA vs. Sultan Industries Sialkot 2017 CLD 1117 (PET)

DG EPA vs. Syed Mansoor Ali Shah Poultry Farm 2011 CLD 1155 (PET)

DG EPA vs. Telenor Company, Gharib Shah 2011 CLD 1067 (PET)

DG EPA vs. Walid Junaid Steel Mills 2011 CLD 1168 (PET)

DG EPA vs. Wi-Tribe 2011 CLD 1138 (PET)

DG Khan Cement Company Ltd. vs. EPA, Punjab 2011 CLD 1351 (PET)

District Officer (Environment) vs. Ghulam Farid Atta Chakki Unit 2016 CLD 778 (PET)

Faisal Iqbal vs. Environmental Protection Authority 2019 CLD 208 (PET)

Haji Muhammad Ismail vs. DG EPA 2019 CLD 80 (PET)

Hussain Industries Corporation vs. EPA, Punjab 2015 CLD 1935 (PET)

Jalal Protien Farm vs. DG EPA 2016 CLD 1416 (PET)

Khalid Ahmed vs. EPA 2017 CLD 328 (PET)

Lafarge Pakistan Cement Company Ltd. vs. DG EPA 2011 CLD 1295 (PET)

Lala Pak Bricks Kiln vs. DG, EPA 2016 CLD 913 (PET)

Mian Muhammad Imran vs. Paramount Engineering Works 2011 CLD 1189 (PET)

Mohammad Parvaiz Poultry Farm vs. EPA 2019 CLD 710 (PET)

Naeem Afzal vs. Secretary Production and Industries 2019 CLD 183 (PET)

Packages Limited vs. EPA, Government of Punjab 2008 CLD 1178 (PET) 
Pakistan Mobile Communication vs. DG EPA 2011 CLD 1280 (PET)

Pakistan Oil Fields Pol House vs. DG EPA 2019 CLD 464 (PET)

Pepsi Cola International (Pvt.) Ltd. vs. Punjab EPA 2018 CLD 1429 (PET)

Raheel Majeed vs. DG EPA 2011 CLD 1232 (PET)

RYK Mills Ltd. vs. DG EPA, 2019 CLD 498 (PET)

Sardar Fakhar Imam vs. Taj Paper Mills 2011 CLD 1179 (PET)

Sarfraz Khan vs. Province of Sindh 2010 CLD 1507 (SET)

Shahbaz Ali Hussaini vs. Provincial EPA 2019 CLD 647 (PET)

Shakarganj Ltd. vs. EPA, Punjab, 2016 CLD 1439 (PET)

Shehla Zia vs. WAPDA PLD 1994 SC 693

Shehri-CBE vs. Sindh Environmental Protection Agency 2010 CLD 859 (SET)

Sindh EPA vs. Silver Textile 2019 CLD 698 (SET)

Sindh Particle Board Mills Ltd. vs. EPA 2011 CLD 1271 (SET)

Sumaira Awan, Secretary General vs. Govermt. of Pakistan et al 2008 CLD 1185 (PET)

Syed Haroon Ahmed vs. Dadex Eternit Ltd. 2010 CLD 1555 (SET)

United Ethanol Ltd. vs. EPA, Punjab 2015 CLD 1079 (PET)

United Feeds Pvt. Ltd. vs. Provincial EPA, 2018 CLD 1454 (PET)

Zia Ullah vs. DG EPA 2011 CLD 1360 (PET)

\section{B. Statutes, Rules and Regulations}

Azad Jammu and Kashmir Environmental Protection Act, 2000

Balochistan Environmental Protection Act, 2012

Code of Criminal Procedure, 1898

Constitution (Eighteenth Amendment) Act, 2010

Composition of Offences and Payment of Administrative Penalty Rules, 1999

Environmental Protection Agency (Review of IEE and EIA) Regulations, 2000

Environmental Sample Rules, 2014 (Sindh)

Environmental Sample Rules, 2001

Environmental Tribunal Rules, 1999

Gilgit-Baltistan Environmental Protection Act, 2015

Hazardous Substances Rules, 2014 (Sindh)

Khyber Pakhtunkhwa Environmental Protection Act, 2014

National Environmental Quality Standards (Self-Monitoring and Reporting by Industry) Rules, 2001

Pakistan Environmental Protection Act, 1997

Pakistan Penal Code, 1860

Pollution Charge for Industry (Calculation and Collection) Rules, 2001

Punjab Environmental Protection Act, 1997

Punjab Environmental Protection (Amendment) Act, 2012

Pakistan Environmental Protection Ordinance, 1983

Sindh Environmental Industrial Waste Water, Effluent, Domestic Sewerage, Industrial Air Emission and Ambient Airs, Noise for Vehicles, Air Emissions for Vehicles and Drinking Quality Standards, 2015

Sindh Environmental Protection (Composition [sic] of Offences and Payment of Administrative Penalty) Rules, 2014

Sindh Environmental Protection Act, 2014

Sindh Environmental Protection Agency (Review of Initial Environmental Examination and Environmental Impact Assessment) Regulations, 2014 
Sindh Environmental Protection Tribunal Rules, 2014

Sindh Environmental Quality Standards (Certification of Environmental Laboratories) Regulations, 2014

Sindh Environmental Quality Standards (Self-Monitoring and Reporting by Industry) Rules, 2014

Sindh Hospital Waste Management Rules, 2014

Sindh Prohibition of Non-Degradable Plastic Products (Manufacturing, Sale and Usage) Rules, 2014

Sindh Sustainable Development (Procedure and Utilization) Rules, 2014

\section{Books and Articles}

Ali Zulfiqar, Khan Bushra, Ghani Fazal, and Atta-ur-Rahman, 'Environmental Tribunal: Evaluating its Status and Performance in Khyber Pakhtunkhwa' (2012) 36:1\&2 Journal of Science and Technology, 17.

Ahsan, Irum and Khawaja, Saima Amin, Development of Environmental Laws and Jurisprudence in Pakistan (Asian Development Bank, 2013).

Ashraf, Jahan, 'Functioning of Environmental Protection Tribunals - A First Hand Experience', conference paper delivered at the South Asia Conference on Environmental Justice, $24^{\text {th }}$ to $25^{\text {th }}$ March 2012, Bhurban, Pakistan (on file with the author).

Azfar, Azim and Hassan, Parvez, 'Securing Environmental Rights through Public Interest Litigation in South Asia' (2004) 22:3 Virginia Environmental Law Journal 215.

Farber, Daniel, 'The Implementation Gap in Environmental Law' (2016) 16: 3 Journal of Korean Law 32.

Cole, Daniel H., 'Explaining the Persistence of "Command-and-Control" in the US' in: (2017) University of Indiana Environmental Law Legal Studies Research Paper Series: $380<$ https://papers.ssrn.com/sol3/papers.cfm?abstract_id=3024177> (accessed on 15 September 2019).

Gill, Gitanjali Nain, 'A Green Tribunal for India' (2010) 22 Journal of Environmental Law 461.

Gill, Gitanjali Nain, 'Access to Environmental Justice in India with Special Reference to National Green Tribunal' (2013) 6:4 OIDA International Journal of Sustainable Development 25.

Government of Pakistan, The Pakistan National Conservation Strategy: A Plan of Action for the 1990s (Islamabad, 1992).

Hassan, Jawad, Country Report - Pakistan (2001) 6 Asia Pacific Journal of Environmental Law 319. 
Hassan, Jawad, Manual of Environmental Laws in Pakistan (Lahore 2018).

Hassan, Parvez, ‘Shehla Zia v. Wapda: Ten Years Later’ PLD 2005 J 48.

Kattumuri, Ruth and Lovo, Stefania, 'Decentralisation of environmental regulations in India' (2018) 53 (43) Economic and Political Weekly, 33.

Khalid, Imran S. and Khave, Ahmed Awais, Political Economy of Water Pollution in Pakistan: An Overview, SDIP Working Paper Series: 170 (SDIP, 2019).

Khan, Imran. The Current State of Environmental Impact Assessment [EIAs] in Pakistan and the Way Forward (Heinrich Böll Stiftung, Islamabad, 2017) at < https://pk.boell.org/2017/12/26/current-state-environmental-impact-assessments-eiaspakistan-and-way-forward> (accessed 4 July 2019).

Lau, Martin, 'The Right to Public Participation: Public Interest Litigation and Environmental Law in Pakistan' (1995) RECIEL, Vol. 4:1, 49-50.

Lau, Martin, 'A New Dawn: The Chaudhry Court and the Revival of Environmental Law', in: Moeen Cheema and Ijaz Shafi Ghani (eds), The Politics and Jurisprudence of the 'Chaudhry Court' 2005-2013 (OUP, 2014) 141 -159.

Malik, Ayesha, The Handbook on Environmental Law, (Punjab Judicial Academy, n.d.) at < http://www.pja.gov.pk/system/files/The\%20Handbook\%200n\%20Environmental\%20Law\% $20 \% 28 \mathrm{v} 4 \% 29 . \mathrm{pdf}>$

Malik, Sonia, Environmental Tribunal: Only 15\% of Cases Decided, 20\% of Fines Recovered, The Express Tribune (Lahore 3 June 2012) https://tribune.com.pk/story/387884/environmental-tribunal-only-15-of-cases-decided-20-offines-recovered/ (accessed 1 July 2019)

Naureen, Mujahida, Development of Environmental Institutions and Laws in Pakistan [2009] 30:1 Pakistan Journal of History and Culture 93

Pastakia, Firuza, Environmental Protection and the Eighteenth Amendment (IUCN, 2012)

Ping, George and Pring, Catherine, Environmental Courts \& Tribunals. A Guide for Policy Makers (UNEP, 2016).

Preston, Brian J., Characteristics of Successful Environmental Courts and Tribunals (2014) 26 Journal of Environmental Law 365

Rose, Gregory, Gaps in the Implementation of Environmental Law at the National, Regional and Global Level, Kuala Lumpur (Malaysia: UNEP, 2011), 28 < https://pdfs.semanticscholar.org/7f63/74c9f59c861007e09bd93e69eddf78cd0ebd.pdf> (accessed 7 July 2019) 
Rosencranz, Amin and Videh Upadhyay, 'Some Suggestions and Recommendations towards a Model State Pollution Control Board (SPCB) in India' (2011) 1 Environmental Law \& Practice Review 106

Tanoli, Ishaq, Environmental Tribunal not working for 20 months, Dawn (Karachi 7 April 2014) https://www.dawn.com/news/1098211 (accessed on 5 July 2019) 
(c) Koninklijke Brill NV, Leiden, 2021. This is the accepted version of an article published by Brill in Yearbook of Islamic and Middle Eastern Law Online: https://doi.org/10.1163/22112987 02001002

Accepted version downloaded from: https://eprints.soas.ac.uk/32989/ 